УДК 391:316.73(497.115:=18)

https://doi.org/10.55302/MF2180179b

Diba Celina Baymak

\title{
CHARACTERISTICS OF TRADITIONAL CLOTHING OF ALBANIAN PEOPLE IN PRIZREN
}

\begin{abstract}
The need for dressing, as one of the basic needs of people, which is similar to the need for food and shelter, has followed a process parallel to the development of humanity. Dresses which were worn only for protection from the cold in the early ages became a sociological concept and were used as a means of differentiation. Nations dressed according to their lifestyles and have created dresses according to their traditions and customs. Each country, region, even each town, has its own dress types.

Each society has a historical experience behind itself and this experience reflects on its cultural elements which then create the traditional structure. The lifestyles that emerged as a result of modernity not only distanced societies from their traditional structures but they also resulted with changes of many material and spiritual forms. The most obvious examples of these changing forms can be witnessed in wedding ceremonies and bridal dresses.

During the examination of historical process, it can be observed that the change brought by modern life at each stage affected the customs and the brides' ceremonial dresses. The wedding ceremony is the most special day in one's life and our interest here is to examine why the traditional wedding dresses were replaced by white wedding dresses. Considering that marriage ceremonies and bridal dresses were created throughout history, it is important to prevent their disappearance and in order to do so, we need to document them and conserve that knowledge for future generations.

This study researches the changes of public dresses within the historical process in the municipality of Prizren (Kosovo) where the design features are determined by the pattern, shape, fabric and decoration. We also tried to determine the opinions of people based on this change of wedding dresses i.e. the change between the traditional and the modern. In Kosovo, which is home to different cultures, the number of previous research studies on societal dressing culture is almost non-existent. In particular, as a result of cultural interaction, the changes in the societal dressing culture have not been adequately addressed. We believe that with this research we will shed light on both the past and the future of the types of dresses that belong to different cultures that are at the forefront of the cultural richness of our country.
\end{abstract}

Keywords: Prizren dressing culture, global interaction, local dresses, customs, change in dressing culture.

\section{INTRODUCTION}

When the clothing in Prizren is examined in terms of many features, regionality (as in regional characteristics of the dresses that make them different from dresses from other regions) constitutes the main lines of differentiation between people. Although there are some common features of the dresses of the people living in various regions of Prizren, again, their patterns vary by regions (Tezcan 1995: 263). It is known that the traditions and customs influence this differentiation and it is especially celebrated in the special ceremonies of the days which constitute the cornerstones of life such as birth, marriage and death. In these 
ceremonies, which are formed according to the customs and value judgments of the regions, the dresses which are in the forefront, visually get local characteristics. It is known that clothing in wedding ceremonies, especially bridal gowns, which have a special place in people's life, have an important place today as they had in history.

Prizren creates a colorful mosaic. Therefore, cultural cohesion is inevitable. Albanian, Turkish, Bosnian and Serbian people have lived together for many years and it is a reality phenomenon that shows mutual influence between these cultures. Although traditions and customs are unique in terms of color, they are also closely related to each other. They figuratively built cultural and art bridges with each other. We see the common point in the tradition of henna burning as well as dressing among the Albanian, Turkish, Bosnian and Serbian people, which are the research subject as we have mentioned. We can say that dressing culture is a sort of a tradition that builds mutual friendship.

\section{THE METODS OF RESEARCH}

\section{Model of the research}

In this descriptive study based on the screening model, which aims to document the change in Prizren's local dresses throughout the history, we used the historical method, which is the method used in research of events and phenomena that occurred in the past or in investigation of a problem in relationship with the past. The research is consisted in examining and consulting relevant literature, as well as finding local dresses and visual documents in field research. To complete this research, locals have been interviewed and all gathered data helped in determining the design features of the local dresses.

\section{Measuring Tools/Data Collection Tools}

In order to establish the measurement tools used in the collection of the research data, in accordance to the expert opinions, by conducting literature review and by researching studies and the related resources, three different measurement tools should be prepared.

In order to determine the design features of the local dresses and photographs, the dressing review form - which includes the photograph, the fabric, the color, the pattern, as well as the use of the dress, - should also include the interview form which is needed to obtain information from the source people, as well as the questionnaire that consists of questions about source people's opinions on traditional and modern dresses.

\section{CHARACTERISTICS OF TRADITIONAL CLOTHING OF ALBANIAN PEOPLE Albanian Women's Clothings}

As the Albanian nation is dispersed in many regions and countries in history and today, its traditional clothing has varied from region to region. Women's 
clothing also varies according to the places women live in, according to their socioeconomic status and even the places they go to (to a funeral, to a wedding, etc.).

We should first start with shirts. Shirts are usually made of woven or transparent fabric. These shirts are usually made of white or self-glitter fabrics. They are also available with shirring elbow. Another piece is the Xhamadan (vest). Xhamadan's are of single color and they usually are embroidered short jackets that are worn over shirts. Some are sleeveless, while some others are long sleeved. Instead of xhamadan, certain robes (caftan) are worn. These robes are long, usually in single color and embroidered. These embroideries are usually done on a dark background. Colored or patterned caftans are not preferred. Today, these caftans are preferred especially at weddings and henna nights. They are widely used in Korcha, Berat, Skopje and Kosovo.

Another piece is "dimi". This piece is a white shawl that women wear instead of skirts, commonly worn in Tirana, Skopje and Kosovo. Another piece is Xhubleta (Cubleta), a bell-shaped skirt that expands towards the end, worn in northern Albania as well as in the mountainous regions of Kosovo. The Xhubletas worn by women today are black, while those of young girls are black and white.

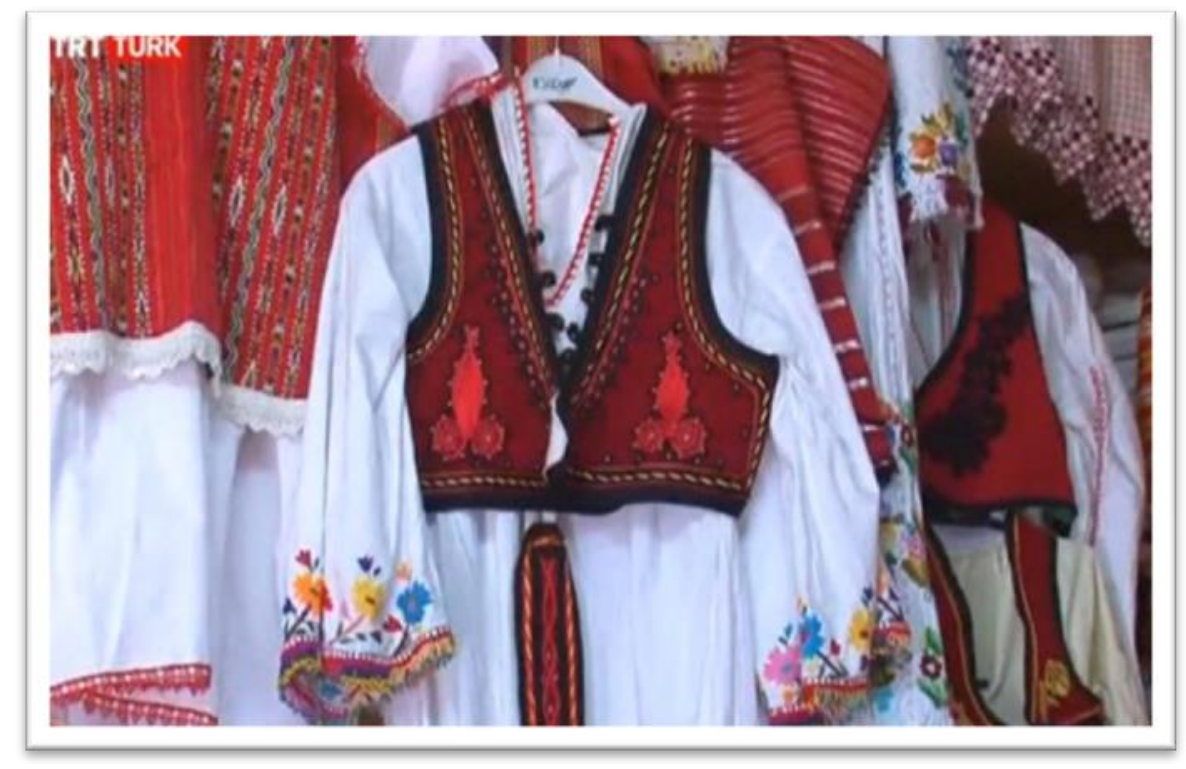

Albanian National Vest (Xhamadan) 


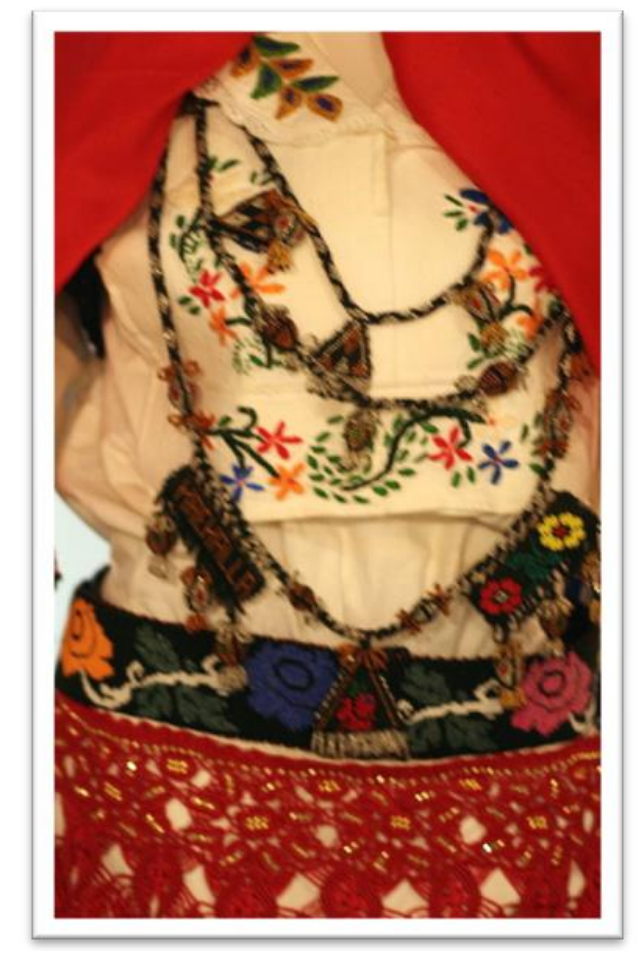

Young women's apparel. The floral crown symbolizes vitality and youth

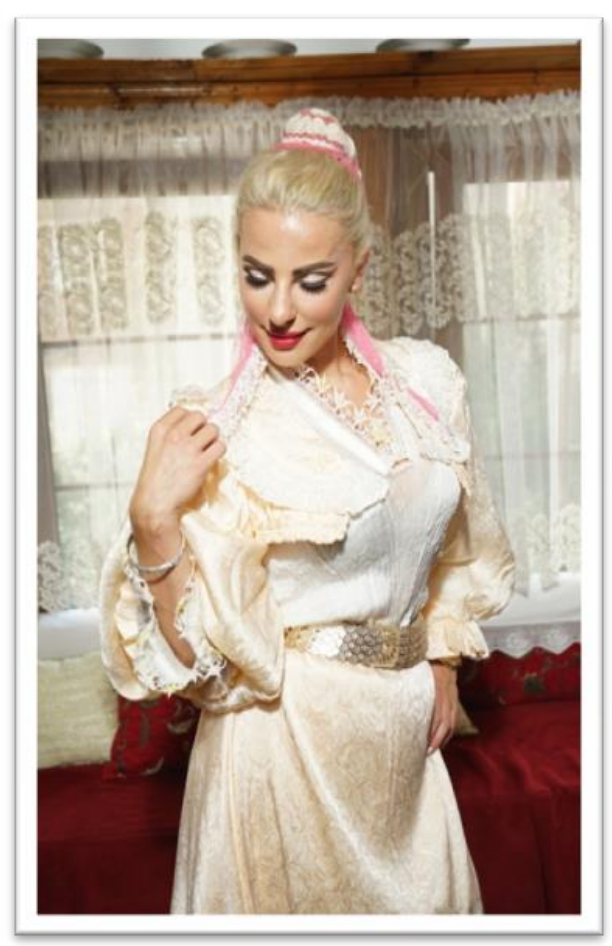

Prizren woman's apparel characterized by lace

\section{Albanian Men's Clothing}

Albanian clothing varies from region to region. The possible reasons for these changes are religious, socio-economic and geographical. In this study, we will primarily focus on what Albanian men wear. When speaking of the main accessories of these clothes, it can be said that Plis or Qeleshe (hat) is one of the most important accessories. "Plis" etymologically means "object made of wool". "Qeleshe (leshe)", on the other hand, means "wool" in Albanian, while "Qe" means "with" in Turkish. So, it means "woolly". In ancient times, Albanians would shave their hair and wear Plis or Qeleshe. According to one belief, this tradition is based on a ceremony held in Ancient Rome. At this ceremony, after the slaves were freed, their hair was shaved and then a white hat representing freedom was put on their head. The production of this accessory (plis), which is based on the belief originating from ancient Rome, currently continues just in Prizren. Although the majority of the Plis's are white, there are also black ones, especially in South Albania. Most Plis's are oval in shape but they can also have flat or tailed (tufted) shapes.

One other change is that the Plis worn in the Rugova region of Kosovo has a white and long cloth on it. Its meaning is as follows: Albanians have wrapped their 
shrouds in their hats, which both always reminds them of death and shows how brave they are.

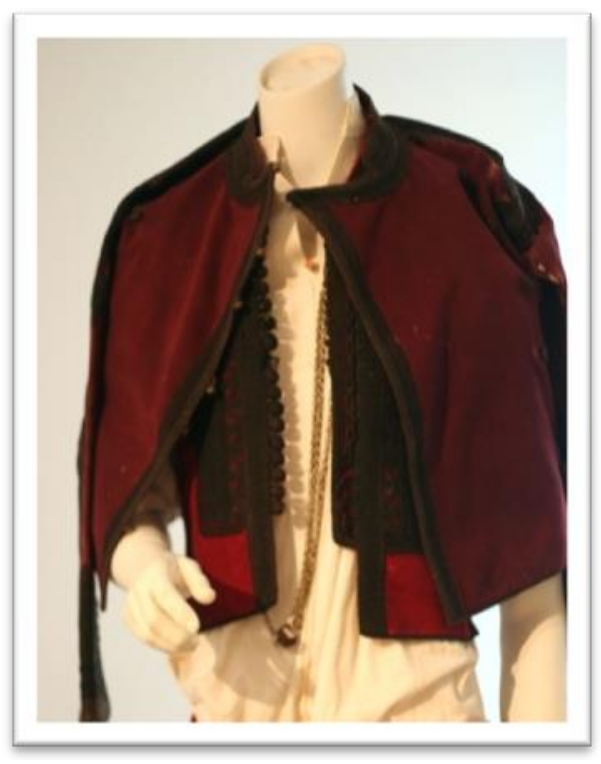

Men's Mitan, Xhamadan

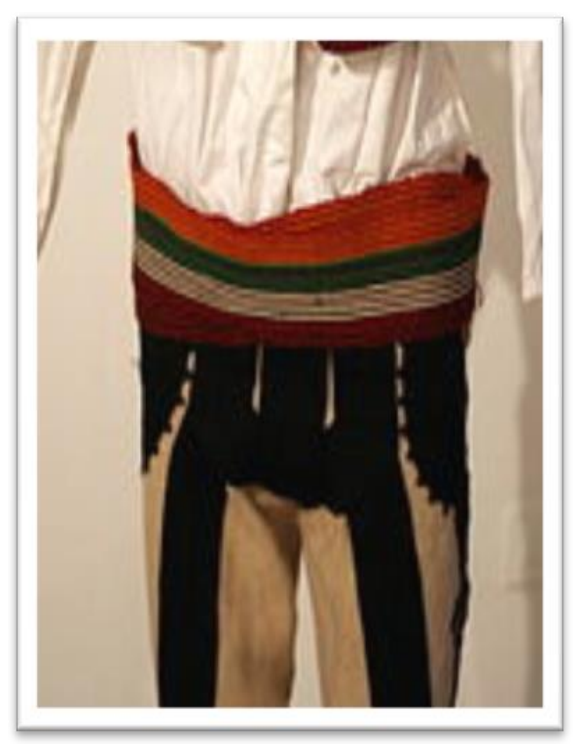

Male Tirqi apparel and Shoke

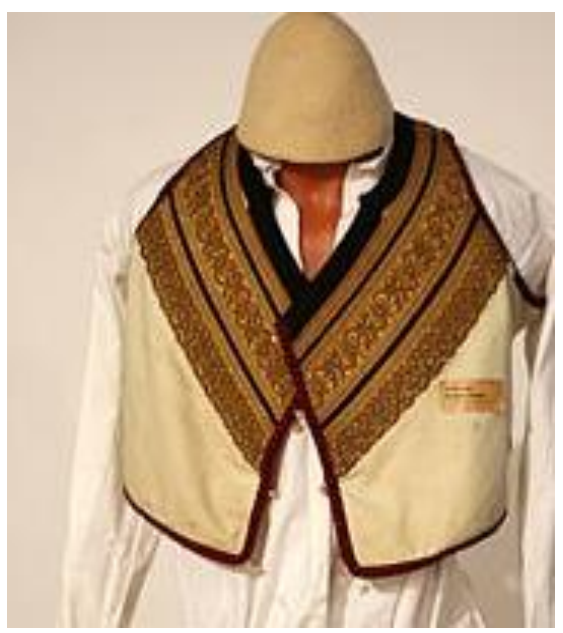

Male Tirqi apparel

Another piece of clothing is a Xhamadan, a vest or a jacket. Although it varies from region to region, it usually appears with sleeves or is in a sleeveless form. Xhamadan has two pockets, one in front and one inside. The villagers' Xhamadan is simpler and monochromatic, while the rich people's ones are 
patterned and more colorful. The quality of the Xhamadan used to be an indicator of class.

Another piece of traditional clothing is Tirq (Trousers). Mostly Northern Albanias, Albanians from Kosovo and Macedonian Albanians (Ghegs) wear these. There are often black embroideries on the front, sides and legs of the trousers. The general color of the trousers is white or ivory. The excess of embroideries is again a status indicator. The line next to the pants is called Gaytan (gimp). In the north of Kosovo we can also find gray trousers. As an auxiliary accessory are used Brez (belt), Socks and Opinga (Shoes). Brez is made of cloth and is wrapped around the waist and it is either black or red. Socks are made of wool to protect men from the cold in winter. In the south it is worn up to the knee, while in the north up to the ankle. Opinga, on the other hand, is made of animal skin and the patterns and colors on it are an indicator of wealth. The Opingas in the North are more standing, and the Opingas in the South are more flamboyant and more ornamental.

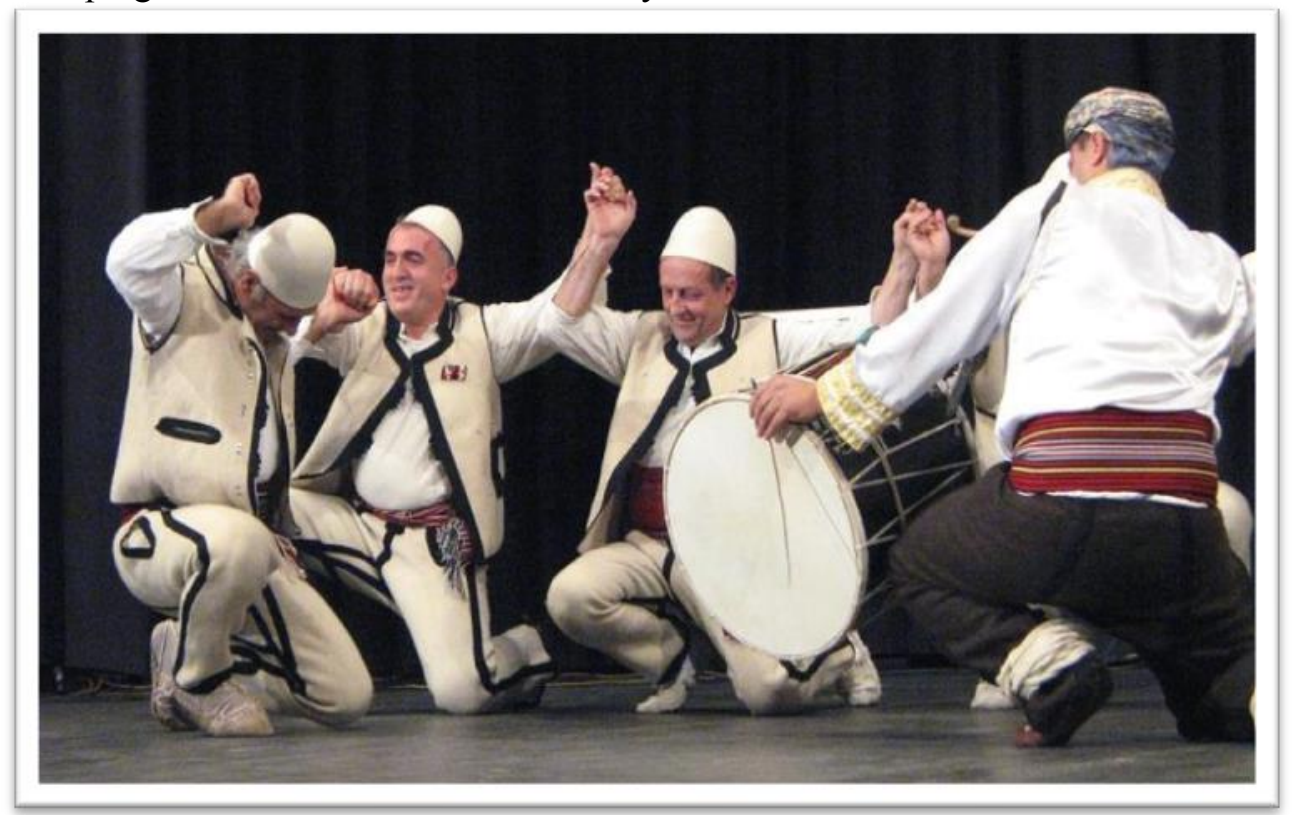

Traditional costumes for men of Prizren, characterized by marhama

\section{Traditional Clothing characteristics of Prizren - Has Local People}

The Has region in Prizren has a very rich culture. Although it is said that the traditions and customs of the specific region can be found in the Luma region which is connected to the city of Kukës of the neighboring country Albania, this is not true. With the collapse of communism on the Balkans, Has region began to adopt its own culture. It can be seen that over time the traditional clothing style of the region starts to resemble more to the clothing style of the city of Gjakova.

If we generally analyze the traditional clothes of the Has region then the most important ones are the white shirts and serge vests that catch the eye among the 
women, which are carefully decorated with beads. Women wear short white trousers at the bottom and then long white trousers. Traditional aprons consist of two parts. The first one is longer on the front and it has warm colors and traditional motifs. The second one, the back part, is shorter.

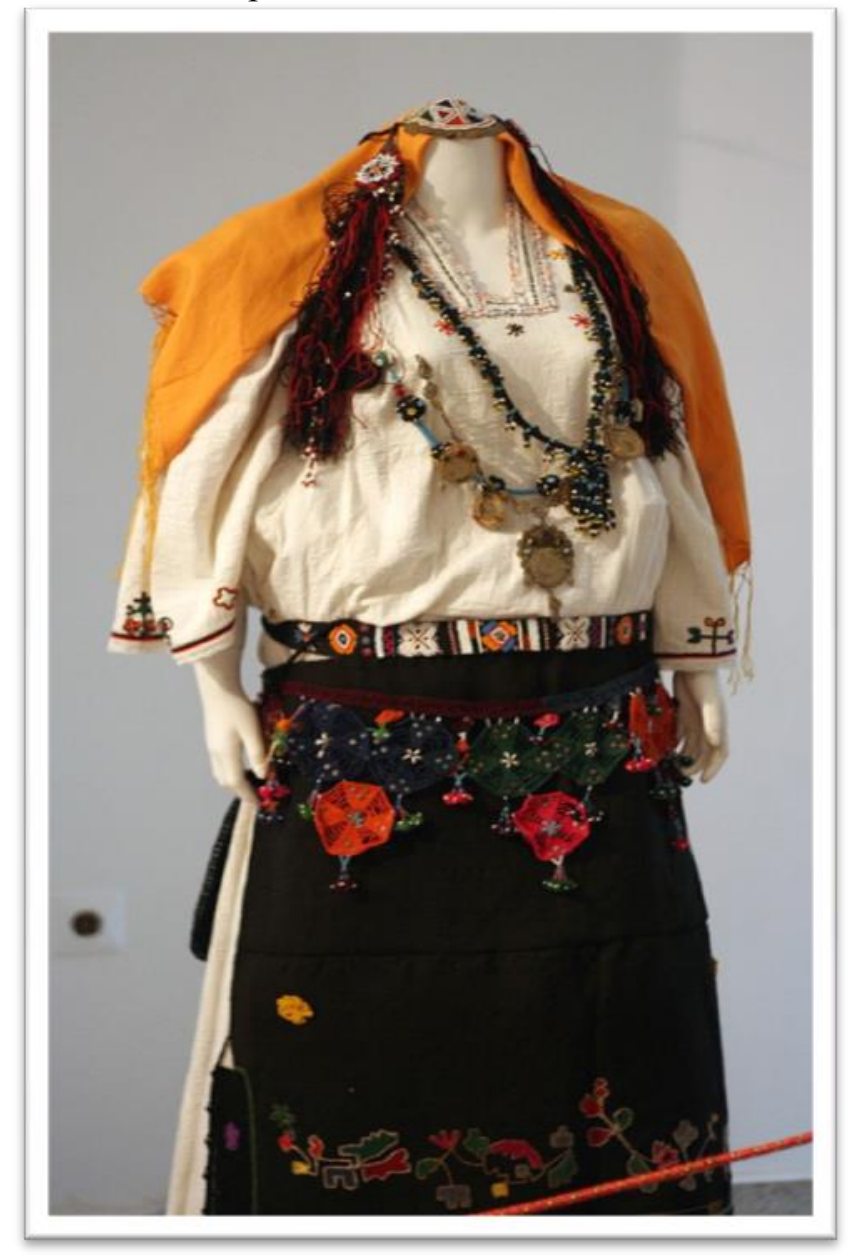

Has clothing for brides after marriage

Another important element is the wooden circle wrapped around the waist. Women used the wooden circle at that time to carry water, water jugs and babies' cradles. A beaded hat with small ornaments is attached to the head. White wool socks are worn on the feet.

Has region is crowned with two clothing styles: the first is Vlahne clothing (shoes, cuffs, shirt, sleeves, back apron, front apron, vest, mahrama, scarf and ornate belt) and the second is Reka clothing (shoes, cuffs, socks, pants, shirts, sleeves, front and back apron, mahramas wrapped around the throat and head, forehead ties, jewelery, beads, and leather belts). On special occasions, brides wear silk shalwars and girls wear towers. 


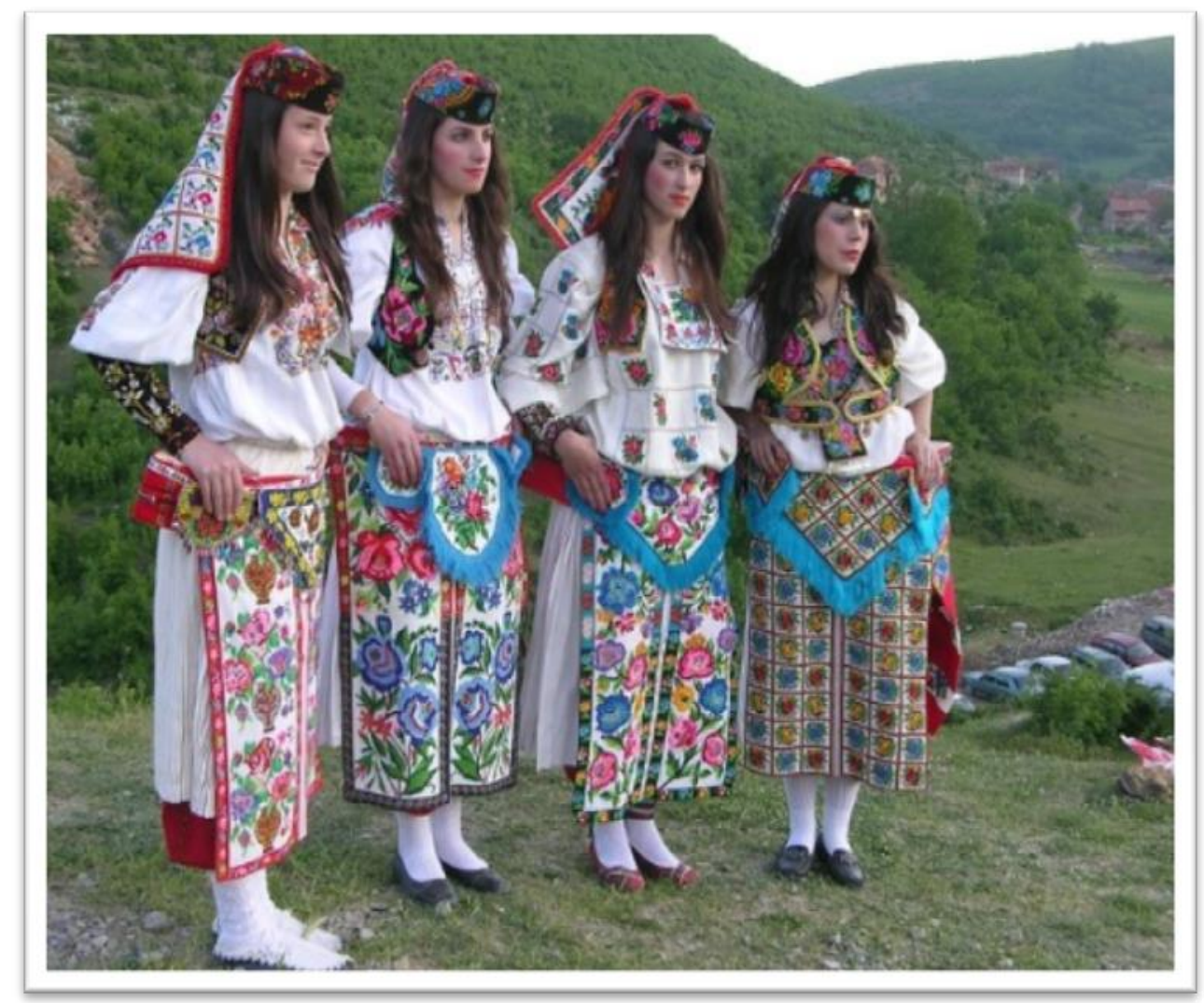

Girls from the region of Has

\section{CONCLUSION}

It is of utmost importance to document, protect and pass on to future generations this knowledge of the traditional dressing code in Prizren in order to prevent the loss of our local dresses, which is one of our cultural values. For this reason, it is important that the local weddings and bridal dresses, which have an important place in the life of people, are properly documented by the experts of the field in all regions. In this respect, it is necessary to raise awareness among the public and to increase the sensitivity of the youth on this issue.

In addition to the work of the Ministry of Culture at central level, municipalities, cultural institutions and organizations in the regions should raise awareness among the public by organizing training activities and events and contribute to those who are interested. Thus, the preservation and protection of the local dresses will be ensured.

The young people's attraction to the subject and the inclusion of the research practices should be done by addressing the research methods and techniques within the educational courses held by institutions. In addition, new designers should be guided by using local elements in the new wedding dresses. 


\section{LITERATURE}

Altınay, H. \& H. Yüceer. 1977. Moda ve Tarihi. Kadığlu Matbaası, Ankara. Aslanpava, O. Türk Sanatı. Remzi Kitapevi. İstanbul. Yayınlar1.

Baudrillard, J. 2002. Tam Ekran. (çev. B. Gülmez). İstanbul: Yap1 Kredi

Bottomore, T. \& R. Nisbet. 2006. Sosyolojik Çözümlemenin Tarihi - 1 . İstanbul: Kırmızı Yayınları.

Büyük L. 1994. Genel Kültür Ansiklopedisi. (9. Cilt). İstanbul.

Çetin, E. 2009. Çalışma Hayatında Bedenin Değişen Görünümü. Uluslararası İnsan Bilimleri Dergisi. Cilt: 6, Say1: 1, 73-83.

Çoruhlu, T. 2007. Kayıp Mirasın İzninde. Gora Halk Sanatları. İstanbul.

Görgünay, N. 1985. İzmir-Kemalpaşa Tahtacılarl ile Yugoslavya'dan İzmir'e

Gelen Göçmen Türklerin Gelenekli Gelin Giysisi. İstanbul: Türk Dünyas1 Araştırmaları, Sayı 34.

Kaya, L. 2007. Mesleki Eğitim Fakültesi Giyim Endüstrisi ve Moda Tasarımı Eğitimi Bölümü Moda Tarihi Dersi İçin Örnek Bir Model Önerisi ve Ínternet Ortamına Aktarılması. Yayınlanmamış Yüksek Lisans Tezi. Ankara: G. Ü. Eğitim Bilimleri Enstitüsü.

Koç, F. \& Koca, E. 2007. Geleneksellikten Modernliğe Geçiş Sürecinde Giyim Anlayışının Değişimi. Prof. Dr. Taciser Onuk’a Armağan. Ankara: Kültür Ajans Yayınları, 244-245.

Koç, F. \& E. Koca. 2009. "Türkve Dünya Kültüründe İstanbul". 7 Uluslararası Türk Kültürü Kongresi. İstanbul, 05-10 Ekim, 560-576.

Siqesa, S. 2006. Koleksioni i Armeve dhe $i$ Stolive ne Kompleksin Monumental te Liidhjes Shqiptare te Prizrenit. Prizren.

Siqesa, S. 2017. Prizren Crafts and Handicrafts in the Monumental Complex of Albanian League of Prizren. Prizren: MKRS-Qendra Rajonale per Trashegimı Kulturore.

Vırmiça, R. 2008a. Prizren'de Kültür, Sanat ve Şairlik Geleneği. Prizren: Kosova Türk Araştırmacılar Derneği Yayınları.

Vırmiça, R. 2008b. Kosova'da Tarih, Kültür, Gelenek ve Göreneklerimiz. Prizren: Kosova Türk Araştırmacılar Derneği Yayınları.

Vırmiça, R. 2018. Prizren Türk Halk Türküleri ve Hikayeleri. Prizren: Kosova Türkleri Milli Bayramı Tertipleme Kurulu.

Vural, T., F. Koç, \& E. Koca. 2011. "Yabancı Kültürlerin Osmanlı Giyim Kuşamına Etkileri”. CIEPO - 18 International Committee of Pre-Ottoman and Ottoman Studies. 18 Symposium. Zagreb, Filozofski Fakultet Sveučilišta u Zagrebu. August 25-30. Zagreb, 155-172.

Yağlı, S. 2012. "Gündelik Hayatın Bir Alanı Olarak Moda Aracılığıyla Kültürün Yeniden İnşası”. İstanbul Arel Üniversitesi, İletişim Fakültesi İletişim Çalışmaları Dergisi/Journal of Communication Studies, Sayı: 3. 
Диба Целина Бајмак

\section{КАРАКТЕРИСТИКИ НА ТРАДИЦИОНАЛНАТА ОБЛЕКА НА АЛБАНЦИТЕ ВО ПРИЗРЕН}

\section{Резиме}

Трудот ја истражува важноста на традиционалната облека на Албанците во Призрен (Косово) за да укаже на промените што ги носи модерниот начин на живот и на фактот дека традиционалната облека, доколку не биде соодветно документирана, може да падне во заборав. Затоа, задача на истражувачите е да вршат не само теренски истражувања во различните косовски региони, туку и преку прашалници, интервјуа со локалното население и преку фотографирање на достапните парчиња на традиционална облека, да дојдат до сознанија за начинот на облекувањето на албанските мажи и жени од Призрен, со посебен акцент на венчалните фустани и машката традиционална облека, кои сѐ повеќе се менуваат во согласност со модерните промени на секојдневниот живот. 